JOURNAL

OF TOURISM

AND ECONOMIC
Journal of Tourism and Economic Vol.4, No.1, 2021, Page 47-59

ISSN: 2622-4631 (print), ISSN: 2622-495X (online)

Email: jurnalapi@gmail.com

Website: http://jurnal.stieparapi.ac.id/index.php/JTEC

DOI: https://doi.org/10.36594/jtec.v4i1.110

\title{
STRATEGI PEMULIHAN DAMPAK WABAH COVID PADA SEKTOR PARIWISATA DI DAERAH ISTIMEWA YOGYAKARTA
}

\author{
Pangky Arbindarta Kusuma \\ Email: pangky.arbi@gmail.com
}

\section{DyahMutiarin}

Email: mutiarin@umy.ac.id

Janianton Damanik

Email: antondmk@ugm.ac.id

\begin{abstract}
The shocks caused by the Covid-19 pandemic had a major impact on the tourism sector and the economy. Yogyakarta is one of the main destinations for domestic and international tourism in Indonesia. Unfortunately, the tourism sector in Yogyakarta is also affected by the COVID-19 pandemic. This study aims to analyze the impact of the Covid-19 pandemic on the tourism sector and recovery strategies during and after the Covid-19 pandemic in the Special Region of Yogyakarta. This research was compiled using a descriptive qualitative methodology, data collection was carried out by studying literature and interviews with resource persons. The results showed that the growth of tourists during the pandemic period was negative, as well as the growth rate of hotel occupancy was also negative. The tourism industry perpetrators suffered huge losses and many workers were sent home without being paid until they were terminated. The recovery of the tourism sector requires a long stageand will be carried out in stages. The first phase has been started in june 2020 and is expected to move towards a new normal in 2022. Several action plans are drawn up for the recovery process. The action plan includes developing health protocols, creating digital tourism, a tourism information system, and SMART Tourism. Local governments and tourism industry players in DIY need to build SMART Tourism for sustainable tourism after the Covid-19 pandemic.SMART Tourism is an innovation in the tourism sector by utilizing information technology in integrating tourism activities.
\end{abstract}

Keyword: Covid-19, Tourism, Recovery Strategy 


\begin{abstract}
ABSTRAK
Guncangan yang ditimbulkan oleh pandemic Covid-19 berdampak besar pada sector pariwisata dan perekonomian. Daerah lstimewa Yogyakarta merupakan salah satu tempat tujuan utama wisata domestic dan internasional di Indonesia. Sayangnya, sector pariwisata di Yogyakarta pun terdampak pandemic COVID-19. Makalah ini bertujuan untuk menganalisis dampak pandemic Covid-19 bagi sector pariwisata dan strategi pemulihan di masa dan pasca pandemic Covid-19 di Daerah Istimewa Yogyakarta. Makalah ini disusun dengan menggunakan metodologi kualitatif deskriptif, pengambilan data dilakukan dengan studi literature dan wawancara kepada narasumber. Hasil penelitian menunjukkan bahwa pertumbuhan wisatawan selama masa pandemic negatif, demikian pula tingkat pertumbuhan hunian hotel juga negatif. Para pelaku industry pariwisata mengalami kerugian besar dan banyak tenaga kerja yang dirumahkan tanpa dibayar hingga mengalami pemutusan hubunga kerja. Pemulihan sector pariwisata memerlukan tahapan yang panjang dan akan dilakukan secara bertahap. Tahap pertama dimulai bulan Juni 2020 dan diharapkan akanmenuju new normal di tahun 2022. Beberapa rencana aksi disusun untuk proses pemulihan. Rencana aksi meliputi penyusunan protocol kesehatan, membuat pariwisata digital, system informasi pariwisata, dan SMART Tourism. Pemerintah daerah dan pelaku pariwisata di DIY perlu membangun SMART Tourism untuk pariwisata berkelanjutan pasca pandemic Covid-19. SMART Tourism adalah inovasi di sector pariwisata dengan memanfaatkan teknologi informasi dalam mengintegrasikan kegiatan pariwisata.
\end{abstract}

Keyword :Covid-19, Pariwisata, Strategi Pemulihan 


\section{PENDAHULUAN}

Virus corona yang disebut lebih lanjut sebagai Covid-19 dinyatakan sebagai pandemic oleh Organisasi Kesehatan Dunia(World Health Organization WHO) sejak bulan Maret 2020. Penggunaan istilah pandemic dikarenakan adanya peningkatan jumlah tiga kali lipat Negara terjangkit dan 13 kali lipat jumlah kasus baruCovid-19. Hal itu menjadi indikasi bahwaCovid-19 dapat melanda seluruh dunia dan berimplikasi pada semakin luas dan besarnya dampak yang terjadi. Pandemi ini berdampak secara multidi mensi karena bukan hanya pada kesehatan manusia, namun juga memiliki dampak social ekonomi (Wen et al., 2020; Nicola et al., 2020; Ozili dan Arun, 2020). Guncangan yang ditimbulkan oleh pandemic Covid-19 menimbulkan kerugian yang sangat besar dan global, lebih buruk dari pada krisis keuangan global. Jika tidak dikelola dengan baik, dapat menyebabkan pengangguran missal dan penutupan bisnis. Serangkaian krisis lainnya akan mengikuti, seperti krisis keuangan, sektoral, neraca pembayaran, dan krisis utang (Loayza dan Pennings, 2020). Menurut Maliszewska et al. (2020) puncak dampak pandemiCovid19 akan dirasakan lebih besar pada sector layanan domestic dan pariwisata. Karena menghasilkan krisis global, maka penanganannya juga haru ssecarag lobal.

Pariwisata saat ini telah mengalami perkembangan yang sangat pesat (Nur Rohman dkk., 2020) sehingga pariwisata menjadi salah satu sektor jasa yang paling terpukul oleh pandemi Covid-19 karena terjadinya penurunan pada penawaran dan permintaan perjalanan yang mengakibatan turunnya pula harga-harga pariwisata. Chanona et al (2020) menyatakan pendapat yang selaras bahwa permintaan pariwisata berubah selama masa pandemi karena sektor pariwisata menempatkan masyarakat pada resiko rentan terinfeksi. Bakar dan Rosbi (2020) pun sepakat bahwa kebijakankebijakan yang ada berdampak pada penurunan konsumen, kehilangan pendapatan bisnis, pemutusan hubungan kerja yang mengakibatkan semakin tingginya jumlah pengangguran di sebuah negara

Daerah Istimewa Yogyakarta (DIY) sebagai salah satu daerah yang memiliki kasus infeksi Covid-19 yang cukup banyak di Indonesia menerapkan berbagai kebijakan dalam upayanya menanggulangi penyebaran Covid-19 agar tidak meluas dan menginfeksi lebih banyak masyarakat. Salah satu kebijakan yang berdampak langsung kepada sektor pariwisata yaitu adanya status tanggap darurat bencana Corona Virus Disease 2019 (Covid19) di DIY mulai tanggal 20 Maret 2020 sampai dengan tanggal 29 Mei 2020. Salah satu yang jadi perhatian dari status tanggap darurat tersebut adalah usaha yang berpotensi menjadi titik kumpul banyak orang lebih dari 20 orang (antara lain destinasi wisata, bioskop, tempat hiburan, atau usaha sejenisnya) apabila masih dilaksanakan untuk menjaga jarak satu orang dengan orang lain minimal 1,6 meter dan wajib mengikuti prosedur pemerintah atau akan ditutup operasionalnya jika tidak mematuhi protokol kesehatan.

Pembatasan kegiatan operasional jasa wisata berdampak langsung kepada pariwisata di DIY, mengingat DIY merupakan daerah tujuan wisata favorit di Indonesia. Kondisi tersebut berlanjut ketika DIY ditetapkan sebagai daerah pemberlakuan Pembatasan Sosial Berskala Besar (PSBB) yang mana segala jenis aktivitas pariwisata secara tegas dilarang sebagaimana diatur dalam Surat Keputusan Menteri Kesehatan Nomor HK.01.07/MENKES/259/2020.

Terhentinya sektor pariwisata tidak hanya terjadi di jenis wisata budaya, wisata belanja dan wisata kuliner yang mana DIY sudah terkenal dengan jenis wisata tersebut, tetapi juga terhadap jenis wisata lainnya seperti wisata sejarah, wisata alam dan wisata minat khusus. Implikasi dari kondisi tersebut berdampak langsung kepada pariwisata yang ada di DIY. Kerugian tidak hanya berdampak kepada penyelenggaraan pariwisata secara langsung, tetapi juga kepada sektor industri penunjang pariwisata seperti jasa transportasi/travel, hotel, dan lain sebagainya. Meskipun banyak pihak memprediksi bahwa COVID-19 bisa 
berlangsung sepanjang tahun 2021, akan tetapi kerugian bagi industri pariwisata sudah bisa dirasakan dampaknya pasca diberlakukannya kebijakan Pembatasan Sosial Berskala Besar (PSBB).

Didasarkan kepada permasalahan tersebut di atas, makalah ini menguraikan dampak apa saja yang ditimbulkan dari wabah Covid-19 bagi pariwisata di DIY. Selain itu, makalah ini juga mengulas strategi yang bisa dilakukan sebagai upaya pemulihan pariwisata di DIY kedepannya dan untuk mengurangi dampak pariwisata dengan adanya wabah Covid-19, lebih lanjut langkah aksi dan strategi apa saja yang harus dipersiapkan agar dapat dijadikan pedoman bagi para pemangku kepentingan di DIY guna bersama-sama mewujudkan pemulihan pariwisata

Penelitian sebelumnya yang terkait dengan stratgi di bidang pariwisata menurut scopus.com terdapat 7,023 penelitian. Hasil analisis bilbiografi dari scopus.com dengan menggunakan VOSviewer untuk tema tourism Strategi adalah sebagai berikut:

Sumber: vosviewer (tourism strategy) uncent, implication, india, influence, italy, marketing strategy, risk, satisfaction, taiwan, tourism destination; cluster 2 meliputi big data, context, hospitality, mexico, nature, overtourism, resilience, review, social mediaum, sustainable tourism; cluster 3 meliputicompetitiveness, costumer satisfaction, determinant, evaluation, hospitality industry, relationship, south africa, tourism sector, vietnam; cluster 4 meliputi challenge, future, intention, malaysia, opportunity, portugal, state, value; cluster 5 meliputi culture, design, effect, hotel, integration, iran, motivation; cluster 6 meliputi colombia, covid, ecuador, pandemic, tourism industry.

Untuk tema covid dalam cluster yang sama related dengan tema colombia, covid, ecuador, pandemic, tourism industry. di cluster yang lain related dengan tema application, culture tourism, economic growth, economic policy uncent, implication, india, influence, italy, marketing strategy, risk, satisfaction, taiwan, tourism destination.

Pada penelitian sebelumnya telah diteliti mengenai strategi pariwisata tapi baru ada 10 jurnal yang spesifik membahas strategi pada masa covid, sedangkan di DIY belum

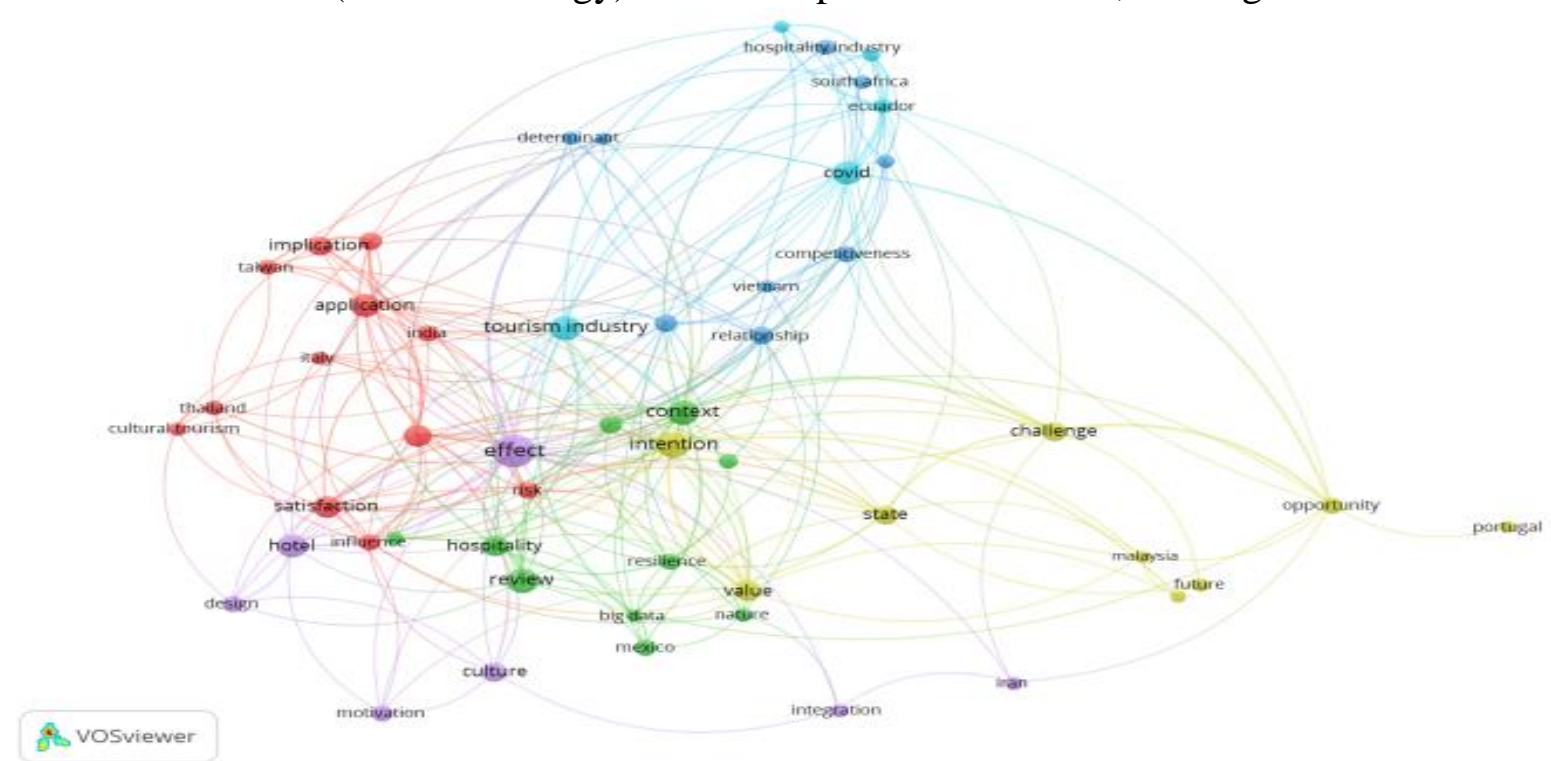

Gambar 1. Bilbiografi tema tourism strategy pada scopus.com (diakses 20 Desember 2020)

Terdapat 6 (enam) Cluster visualiasi data penelitian berdasarkan artikel pada scopus.com yang dianalisa dengan VOSviewer (tema tourism strategy), yaitu: cluster 1 meliputi application, culture tourism, economic growth, economic policy ada penelitian khusus pada strategi pariwisata di Daerah Istimewa Yogyakarta di masa pandemic Covid-19, sehingga pada paper ini akan dibahas mengenai strategi pemulihan pariwisata di DIY akibat dampak wabah Covid-19, dan bagaimana pengaruhnya terhadap pariwisata yang merupakan kunci pembangunan, kesejahtraan dan kebahagiaan (Muhamad Nur dkk., 2020) 


\section{METODE PENELITIAN}

Makalah disusun dengan metodelogi penelitian kualitatif deskriptif. Pengambilan data dilakukan dengan studi literatur dan pengumpulan data langsung dari beberapa kantor dinas terkait. Kantor dinas yang dituju meliputi: Dinas Pariwisata DIY, Dinas Pariwisata Kabupaten/Kota di DIY dan Badan Perencanaan dan Pembangunan (Bappeda) DIY. Milesans Huberman (dalam Sugiyono, 2019) mengemukakan bahwa aktivitas dalam analisis data kualitatif dilakukan secara interaktif dan berlangsung secara terus menerus sampai tuntas. Aktivitas analisis data dalam penyusunan makalah, meliputi: reduksi data, display data, dan penarikan kesimpulan/verifikasi.

Kredibilitas dokumen diolah dengan korelasi Person hasilnya menunjukkan bahwa dari 10Jurnal yang sudah pernah menganalisa tentang strategy, tourismdan Covid-19 saling terkait satu dengan yang lain. Dengan software Nvivo 12 diketahui bahwa nilai korelasi terendah adalah 0,15 dan nilai korelasi tertinggi adalah 1,40. Kredibilitas Jurnal juga dicek dengan fasilitas word frequency untuk mengetahui apakah dokumen yang dianalisis sesuai dengan topik dan tujuan penelitian. Hasilnnya kata-kata kunci tertinggi yang ditemukan adalah "tourism" ada 1.530 kata, "covid" ada 834 kata, "pandemic" 566 kata, "strategies" ada 366 kata, "tourist" ada 348 kata, dan "destination" ada 338 kata, yang delengkapnya dapat dilihat pada gambar 2. Dengan demikian semua dokumen yang dianlisis saling terkait dan memiliki kredibilitas sesuai dengan permasalahan penelitian.

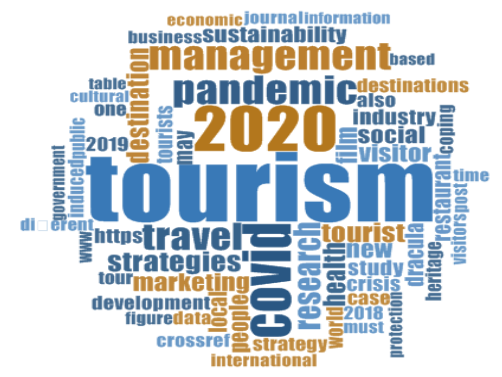

Gambar 2: Hasil Word Frequency pada Aplikasi Nvivo
Data sebagai sumber dasar analisis dalam penelitian ini didapat dengan menggunakan teknik pengumpulan data dokumentasi (documentary study) yang mana berbagai data yang dianggap relevan dengan penelitian yang tengah di lakukan bersumber baik dari buku, jurnal, peraturan perundangundangan, laman web dan sumber referensi lainnya. Data ini kemudian akan diolah melalui tiga tahapan yang terdiri dari reduksi data, penyajian data/display dan penarikan kesimpulan Creswell (2007). Kemudian data tersebut akan dilakukan pengujian untuk menghasilkan gambaran yang real dan benar sesuai dengan kondisi yang ada melalui teknik triangulasi yang meliputi tahap check, tahap re-check dan tahap cross-check (Sugiyono, 2010).

\section{TINJAUAN LITERATUR}

Pandemi Covid-19 telah berdampak negatif pada banyak sektor pariwisata yang berbeda (Gossling dkk., 2020 ; Hall dkk., 2020), akhirnya menyebabkan industri tutup selama berbulan-bulan. Padahal berbagai upaya telah dilakukan sejak Juni 2020 untuk membuka kembaliindustri, sebagian besar sektor terus berjuang dan UNWTO (2020) telah mengakui pariwisata sebagai salah satu industri yang paling terpukul (Dolnicar \& Zare, 2020 ; Gössling dkk., 2020). Krisis adalah kejadian rutin dalam pariwisata( Dolnicar \& Zare, 2020 ; Gössling dkk., 2020). Banyak destinasi yang terpengaruh oleh alamdan krisis buatan manusia dan, selama bertahun-tahun, telah mengembangkan taktik dan strategi ketahanan dan mitigasi ( Ritchie \& Jiang, 2019 ). Namun, krisis yang berasal dari pandemi Covid-19 berbeda dan unik dalam banyak hal. Pertama, penurunan perjalanan, perhotelan, dan pariwisata telah terjadi di seluruh dunia (UNWTO, 2020 ). Kedua, keruntuhan ekonomi lebihdramatis. Ketiga, krisis yang sedang berlangsung berpotensi menyebabkan modifikasi mendasar di banyak segmen pariwisata ( Dolnicar \& Zare, 2020 ). Dan keempat, akhir dari krisis masihbelum terlihat. Baru-baru ini, Yang et al. (2020) mengembangkan 'keseimbangan umum stokastik dinamis' untuk memahami efek pandemi pada pariwisata global. Model 'Penerapan Covid-19 mencerminkan 
penurunan permintaan pariwisata sebagai respons terhadap peningkatan risiko kesehatan.

Tinjauan literatur terkini tentang Covid-19 dan dampak terhadap industri pariwisata mengungkapkan bahwa sebagian besar teks yang telah diterbitkan sejauh ini dapat digambarkan sebagai makalah opini atau catatan penelitian. Misalnya, edisi khusus Geografi Pariwisata Topik ini berisi lebih dari 30 karya tentang cara-cara di mana peristiwa pandemi tahun 2020 dapatberkontribusi pada transformasi industri pariwisata. Karya tambahan juga telah dipublikasikan di jurnal lain dari bidang pariwisata (seperti Annals of Tourism Research, Journal of TravelResearch, dan Jurnal Pariwisata Berkelanjutan) dan bidang lainnya (seperti ekonomi). Hanya beberapa makalah yang telah ditulis menggunakan metode empiris (seperti Yang dkk., 2020 ; Gössling dkk., 2020 ), dan tidak ada strategi yang cocok untuk semua karena dampak pandemic yang berbeda sesuai karakter wilayah masing masing (Head, 2007).

\section{HASIL DAN PEMBAHASAN}

Covid-19 yang sudah menyebar keseluruh provinsi di Indonesia disikapi dengan penetapan bencana nasional COVID-19 oleh pemerintah, status tersebut didasarkan kepada bayaknnya warga masyarakat yang terinfreksi Covid19, bahkan ribuan orang meninggal disebabkan oleh Covid-19 tersebut. Kondisi wabah Covid-19 diperparah dengan belum diketemukannya obat dan vaksin anti Covid- 19, berbagai pihak memprediksi bahwa penyebaran Covid-19 akan berlangsung sepanjang tahun 2020, penelitian yang dilakukan oleh tim simulasi dan permodelan Covid-19 Indonesia (SimcovID) dengan menggunakan model proyeksi SEIQRD (Suceptible-Exposed-Quarantine-

Recovery-Death) menyimpulkan bahwa puncak persebaran Covid-19 akan terjadi di bulan Mei 2020 dengan catatan pemerintah hanya memberlakukan kebijakan pembatasan sosial (PSBB) dan bukan memberlakukan kebijakan karantina wilayah/lockdown (Permana, 2020).

Kondisi tersebut di atas mengkonstruksikan pemahaman akan perlunya perencanaan pemulihan pembangunan pasca Covid-19, hal ini didasarkan bahwa sudah banyak nya dampak negatif yang ditimbulkan oleh Covid-19, sehingga instrument kebijakan yang mengakselersi proses pemulihan pembangunan mutlak diperlukan. Dalam konteks pariwisata, Covid-19 yang disusul dengan pemberlakukan Pembatasan Sosial Berskala Besar (PSBB) berimplikasi kepada berhentinya seluruh kegiatan pariwisata yang ada di DIY yang berimplikasi kepada kerugian ekonomi di sector pariwisata. Pembahasan hasil penelitian ini mengkaji 3 (tiga) pokok bahasa ndalam menyikapi Covid-19 yaitu: Pertama, mengkaji pariwisata di DIY. Kedua, mengkaji dampak Covid-19 di DIY. Ketiga, mengkaji strategi pemulihan sector pariwisata di masa pandemic dan pasca panddemi covid19. Adapun pembahasan ketiga pokok bahasan tersebut dapat dilihat sebagai berikut:

\section{Pariwisata di DIY}

Dalam konteks kepariwisataan, provinsi DI.Yogyakarta memiliki potensi kepariwisataan yang besar dan beragam, baik berupa daya tarik wisata alam, daya tarik wisata budaya (peninggalan sejarah maupun adat tradisi kehidupan masyarakat) maupun khusus. Keragaman daya tarik wisata DIY juga dapat dilihat dari perspektif geografis, mulai dari wilayah pegunungan, wilayah pedesaan dan perkotaan, maupun wilayah pantai/ perairan/ laut.

Rentang waktu 5 tahun terakhir, perkembangan jumlah wisatawan di DIY mengalami peningkatan yang cukup signifikan, terutama pada jumlah wisawatan nusantara.Pada tahun 2019, jumlah wisatawan yang mengunjungi DIY sebanyak 6.549.381 orang yang terdiri dari wisatawan nusantara sebanyak 6.116.354 orang dan wisatawan mancanegara sebanyak 433.027 orang. Secara keseluruhan jumlah tersebut meningkat sebesar $7 \%$ dibandingkan dengan tahun sebelumnya. 
Tabel 1: Pertumbuhan Jumlah wisatawan di DIY

\begin{tabular}{ccccc}
\hline Tahun & $\begin{array}{c}\text { Wisatawan } \\
\text { Mancanegara }\end{array}$ & $\begin{array}{c}\text { Wisatawan } \\
\text { Nusantara }\end{array}$ & $\begin{array}{c}\text { Wisatawan } \\
\text { Mancanegara } \\
\text { dan } \\
\text { nusantara }\end{array}$ & $\begin{array}{c}\text { Pertumbuhan } \\
(\%)\end{array}$ \\
\hline 2015 & 308,485 & $3,813,720$ & $4,122,205$ & 23,19 \\
2016 & 355,313 & $4,194,261$ & $4,549,574$ & 10,37 \\
2017 & 397,951 & $4,831,347$ & $5,229,298$ & 14,94 \\
2018 & 416,373 & $5,272,718$ & $5,689,091$ & 8,79 \\
2019 & 433,027 & $6,116,354$ & $6,549,381$ & 15,12 \\
\hline
\end{tabular}

Sumber: Dinas Pariwisata DIY, Tahun 2020

$\begin{array}{ccr}\text { Dalam } & \text { konteks } \\ \text { perkembangan } & \text { kisman } & \text { wisman, } \\ \text { DIY }\end{array}$
menunjukkan angka peningkatan dari tahun ke tahun. Hal ini sejalan dengan peningkatan wisman pada tingkat nasional. Angka kunjungan wisman pada periode waktu 2017 - 2018sempat menunjukkan penurunan pertumbuhandengan jumlah persentase $4,63 \%$. Pada tahun 2018 ke tahun 2019kembali mengalami penurunanpertumbuhan kunjungan wisman mencapai $4 \%$, namun secara jumlah wisatawan mancanegara di DIY selalu naik setiap tahunnya. Dari rata-rata pertumbuhan kunjungan wisman mulai tahun 2015 2019 mencapai $11,43 \%$.

Dalam konteks wisatawan nusantara (Wisnus), perkembangan Wisnus ke DIY menunjukkan angka peningkatan dari tahun ke tahun. Hal ini sejalan dengan peningkatan wisnus secara nasional, dan juga semakin meningkatnya kemampuan masyarakat untuk melakukan perjalanan wisata sebagai bagian dari kebutuhan psiko sosial seiring meningkatnya pendapatan masyarakat. Pertumbuhan pergerakan wisnus ke DIY pada tahun terakhir menunjukkan peningkatan hingga $15,12 \%$ lebih tinggi dari tahun sebelumnya. Sedangkan rata-rata pertumbuhan wisnus dari tahun 2015sd tahun 2019 adalah $14,73 \%$.

\section{Dampak Pandemi Covid-19 terhadap Pariwisata di DIY}

Pandemi Covid-19 telah berdampak cukup besar pada industry pariwisata di DIY. Sebagai daerah yang mengandalkan perekonomiannya dari pariwisata, pembatasan jarak social dan pembatasan perjalanan berdampak pada berhentinya industry transportasi. Ketika industry transportasi berhenti, maka perjalanan wisata turut berhenti. Sektor pariwisata di
DIY mengalam ikrisis. Kunjungan kedestinasi wisata terhenti, tingkat human hotel, kunjungan kerestoran, transaksi perdagangan yang terkait dengan pariwisata turut mengalami krisis. Banyak pelaku usaha mengalami kerugian sehingga berdampak pada pengurangan tenaga kerja. Perekonomian DIY turut terkena dampak krisis ini (lihatGambar 4).

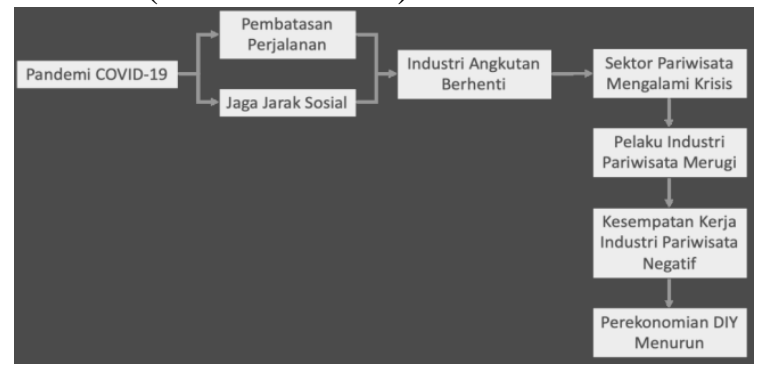

Gambar 3.DampakPandemi Covid-19

Sebelum pandemic Covid-19, kunjungan wisatawan ke DIY mengalami pertumbuhan yang cukup tinggi. Pada tahun 2019 terjadi penambahan jumlah wisatawan yang cukup besar. Pertumbuhan tertinggi pada bulan Juni 2019 sebesar 99,36persen (yoy). Pandemi Covid-19 berdampak pada menurunnya jumlah wisatawan yang berkunjung ke DIY secara signifikan. Selama tiga bulan pertama tahun 2020 , pertumbuhan wisata domestic sebesar 26,41 persen (Januari), 33,51 persen (Februari), dan -60,17 persen (Maret) dibandingkan periode yang sama pada tahun 2019. Pertumbuhan wisatawan mancanegara selama tiga bulan pertama tahun 2020 berturut-turut adalah $-27,37$ persen; 23,83 persen; dan -60,72 persen (lihatGrafik1).

Grafik 1: Perkembangan Jumlah Wisatawan di daerah Istimewa Yogyakarta

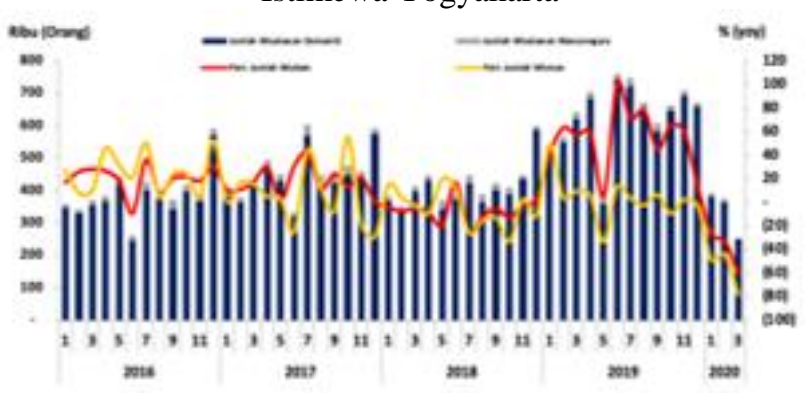

Sumber: BPS dan Bank Indonesia, data diolah

Turunnya jumlah wisatawan di DIY berdampak pada semua pelaku industry pariwisata di DIY. Kunjungan keobyek wisata, tingkat hunian hotel, konsumen restoran, penjualan souvenir, hingga took oleh-oleh menjadi sepi. Kondisi ini perlu mendapatkan 
perhatian serius karena kontribusi sector pariwisata bagi perekonomian DIY cukup besar.

Seiring dengan meningkatnya jumlah wisatawan pada tahun 2019, tingkat hunian hotel juga meningkat. Selama tahun 2019, rata-rata tingkat hunian hotel bintang mencapai 58,14 persen, sedikit meningkat dibandingkan tahun 2018 sebesar 58,01persen. Tingkat hunian hotel non-bintang 30,02persen, meningkat dibandingkan tahun 2018 sebesar 27,14 persen. Memasuki dua bulan pertama di tahun 2020, tingkat okupansi hotel bintang masih tumbuh dibandingkan periode sama tahun 2019 (yoy). Memasuki bulan ketiga (Maret), pertumbuhan okupansi hotel bintang di DIY -40,29 persen di banding periode sama tahun 2019. Menurunnya jumlah wisatawan ke DIY akibat pandemic Covid- 19 juga menurunkan tingkat hunian hotel di DIY (Grafik 2).

Grafik2: Tingkat Hunian Hotel Berbintang dan non-Bintang di DIY

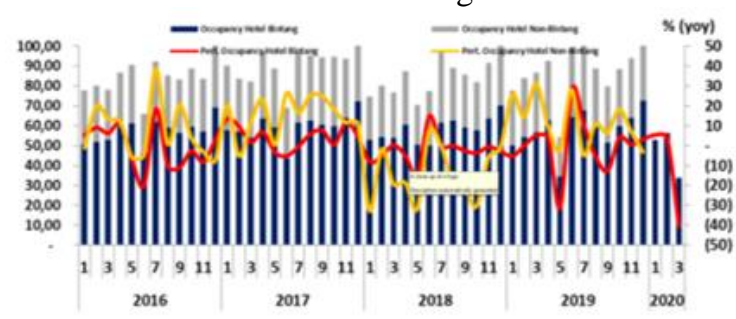

Sumber: BPS dan Bank Indonesia, data diolah

Pertumbuhan transaksi hotel dan restoran selama dua triwulan terakhir hingga triwulan 12020 cukup tinggi. Kondisi ini terjadi sebelum adanya penghentian operasional transportasi umum antarkota antar provinsi di Indonesia. Saat ini transaksi hotel dan restoran dalam kondisi jatuh. Transaksi perdagangan sejak memasuki tahun 2019, pertumbuhannya terus mengalami penurunan. Kondisi ini masih akan terus berlangsung hingga kuartal III tahun 2020 (lihat Grafik3).
Grafik3: Transaksi Perdagangan dan Restoran di DIY

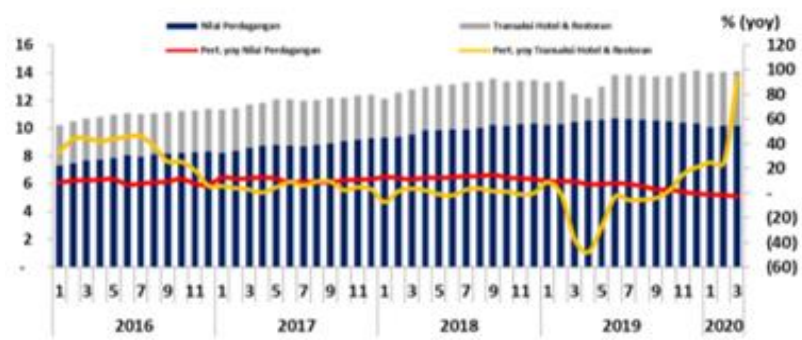

Sumber: BPS dan Bank Indonesia, data diolah

Dampak negatif pandemi juga mengakibatkan penurunan jumlah tenaga kerja di sektor pariwisata. Sektor jasa seperti pariwisata sangat terdampak karena sedikitnya pekerjaan yang bisa dilakukan di rumah. Pelayanan atau obyek yang biasanya menarik wisatawan secara fisik menjadi tidak bisa diberikan maksimal karena kebijakankebijakan untuk menekan kasus Covid-19.

Pada sektor formal terdapat 4.252 tenaga kerja yang stay atau belum terverifikasi, 63 tenaga kerja yang sudah di-PHK, dan 8.666 tenaga kerja yang dirumahkan tanpa dibayar). Tenaga kerja di jasa event memiliki proporsi tertinggi yang belum terverifikasi sebanyak 1.156. Tenaga kerja yang paling banyak di PHK adalah tenaga kerja di destinasi wisata buatan. Sedangkan, tenaga kerja yang dirumahkan tanpa dibayar paling tinggi adalah tenaga kerja yang bekerja pada jasa akomodasi wisata (hotel termasuk MICE) sebanyak 5.440. Hal ini terjadi karena semakin besar penurunan wisatawan berdampak pada menurunnya konsumen akomodasi wisata. Walaupun begitu, estimasi kerugian sampai dengan Maret 2020 paling besar justru dialami oleh jasa perjalanan wisata tour and travel sebesar 11,57 miliar rupiah (Iihat Tabel 2).

Tabel 2 : Pelaku Industri Pariwisata Terdampak di DIY

\begin{tabular}{|c|c|c|c|c|c|c|}
\hline \multirow[t]{7}{*}{$\mathrm{No}$} & \multirow{7}{*}{$\begin{array}{l}\text { Usaha } \\
\text { Jasa } \\
\text { Pariwis } \\
\text { ata }\end{array}$} & \multicolumn{4}{|c|}{ Jumlah Tenaga Kerja } & \multirow{7}{*}{$\begin{array}{c}\text { Estimasi } \\
\text { kerugian } \\
\text { s.d Juni } \\
2020 \\
\text { (Miliar } \\
\text { Rupiah) }\end{array}$} \\
\hline & & Stay/be & $\mathrm{P}$ & Unp & Tot & \\
\hline & & & $\mathrm{H}$ & aid & al & \\
\hline & & terverif & K & Lea & & \\
\hline & & ikasi & & ve & & \\
\hline & & & & Tot & & \\
\hline & & & & al & & \\
\hline \multirow{6}{*}{1} & A. & 4,262 & 62 & 8,66 & 12,9 & 46,82 \\
\hline & $\begin{array}{l}\text { DataSek } \\
\text { toral }\end{array}$ & & & 6 & 90 & \\
\hline & Destina & 911 & 16 & 563 & 1,49 & 7,31 \\
\hline & & & & & 0 & \\
\hline & wisata & & & & & \\
\hline & Buatan & & & & & \\
\hline
\end{tabular}




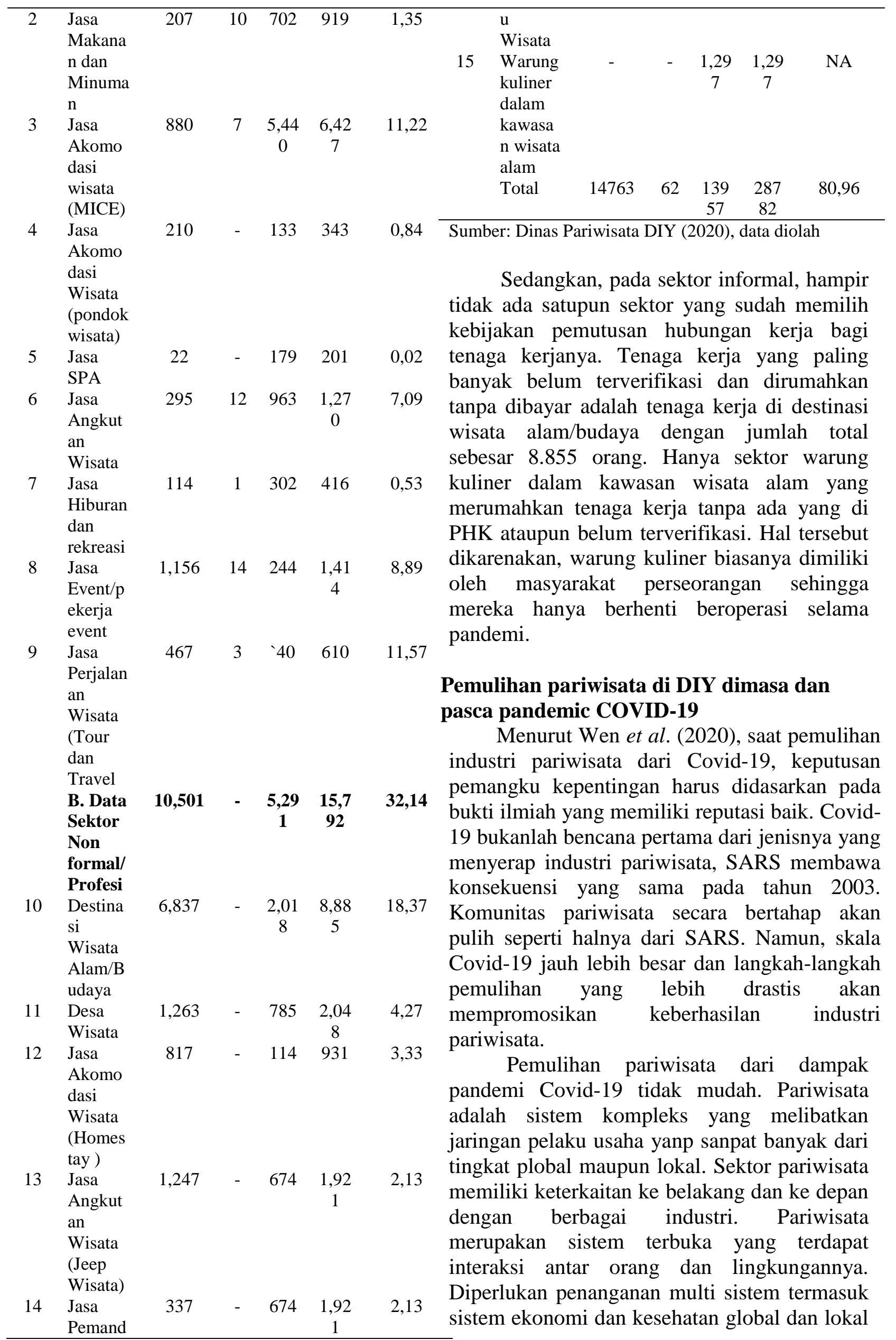


(Khalilzadeh, 2020). Karena memerlukan pendekatan multi sistem, maka WHO tidak sendirian dalam menerbitkan protokol kesehatan. World Health Organization (2020) menerbitkan tiga pernyataan bersama untuk mengingatkan semua pemangku kepentingan tentang pentingnya mengikuti peraturan dan pedoman kesehatan internasional, peraturan organisasi mitra yanp ada, dan perlunya kolaborasi lintas sektor. Pernyataan bersama dirilis masing-masing, dengan Organisasi Maritim lnternasional (IMO), Organisasi Penerbangan Sipil Internasional (ICAO) dan Organisasi Pariwisata Dunia (UNWTO).

Pandemi Covid-19 menurut Nunes (2020) memaksa inovasi di Sektor Pariwisata untuk berbenah diri. Dunia membutuhkan pariwisata yang lebih baik dan inovasi yang lebih baik. lnovasi harus dilakukan agar pariwisata tetap dapat melayani wisatawan dengan lebih baik di masa dan pasca pandemi Covid-19. Perilaku wisatawan akan berubah pasca pandemi Covid-19, sehingga pelaku industri pariwisata juga harus berubah melalui inovasi yang lebih baik

Dewan Perjalanan dan Pariwisata Dunia (the World and Tourism CouncilWTTC)menyatakan bahwa pemulihan pariwisata memerlukan waktu 10 sampai dengan 12 bulan, walaupun begitu UNWTO optimis bahwa proyeksi pariwisata jangka panjang akan mencapai1,9 miliar pada tahun 2030 dan meningkat dua kali lipat percepatan ekonomi menjadi 4,4 persen secara tahunan (kumar, 2020; Ranasinghe, 2020. Persiapan pemulihan sektor pariwisata harus berjalan teliti, rapi dan tanpa kesalahan agar dapat menghasilkan dampak yang positif bagi semua pihak

Pemerintah berupaya membuat kebijakan pemulihan sektor pariwisata secara bertahap dimulai dengan membuka industri perhotelan dan restoran dengan pemberlakukan protokol kesehatan, pelaku industri pengolahan, dan destinasi wisata. Industri Perhotelan dan restoran memerlukan sertifikasi keamanan dan kebersihan untuk meyakinkan konsumen. Penyediaan hand sanitizer, mengatur waktu makan (buffet time)konsumen agar tidak bersamaan yang menimbulkan kerumunan, penataan meja makan yang memberikan jarak antar tiap meja, dan menggunakan transaksi non tunai dapat menjadi terobosan yang dapat dilakukan di industri perhotelan dan restoran

Destinasi wisata juga harus berbenah untuk selalu mengedepankan kesehatan, memberikan fasilitas sesuai protokol kesehatan, menyediakan lingkungan yang nyaman dan terjaga kebersihannya, sepadan dengan harga yang ditawarkan, dan menambahkan adanya atraksi-atraksi baru yang inovatif kreatif. Pihak pengelola destinasi wisata juga harus mulai bekerja secara kolaborasi dengan berbagai pihak lain seperti destinasi lain, agen travel, danmaskapai. Promosi juga harus semakin digencarkan oleh pihak pengelola dengan menggandeng beberapa pihak. Hal ini dapat membuat percepatan pemulihan karena pandangan pihak-pihak tersebut. Promosi dapat dilkukan melalui kerjasama dengan komunitas dan influencer, menggunggah melalui media sosial, dan penawaran promo yang menarik wisatawan

Pemulihan industri pariwisata di DIY akan dilakukan secara bertahap. Tahap pertama sudah dimulai sejak Juni lalu dngan melakukan serangkaian rencana aksi. Rencana aksi yang pertama adalah menyusun protokol K3 (Kesehatan, dan Keselamatan Kerja)untuk semua industri pariwisata di DIY. Setiap pelaku industri pariwisata di DIY harus memiliki unit K3 untuk menjamin pelaku dan pengunjung sehat dan aman. (lihat gambar9)

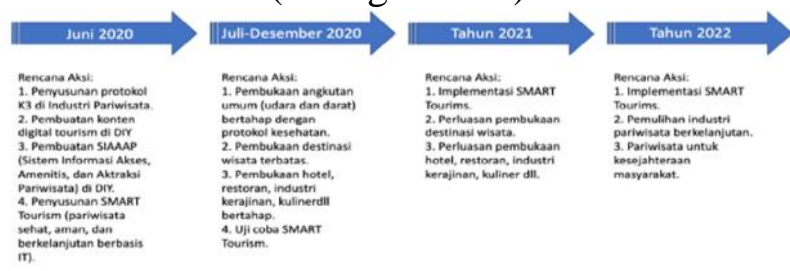

Gambar 4 : Peta Jalan Pemulihan Pariwisata di DIY

Rencana aksi kedua pada tahap pertama ini adalah pembuatan konten digital tourism (wisata digital) di DIY. Wisata digital ini menggambarkan visualisasi perjalanan di destinasi wisata DIY yanp sehat dan aman. Penyusunan digital tourism dapat melibatkan influencer dan penpgiat medsos supaya bisa menarik dan meyakinkan calon wisatawan yang akan berkunjung ke DIY bahwa destinasi wisata di DIY menarik, sehat, dan aman. 
Rencana aksi ketiga adalah pembuatan SIAAAP (Sistem Informasi Akses, Amenitas, dan Atraksi Pariwisata) DIY. Sistem informasi ini menginformasikan akses menuju destinasi wisata; kapasitas pengunjung per hari; pemesanan tiket masuk secara online; ketersediaan tiket masuk secara real time; ketersediaan amenitas yang sehat, aman, nyaman dengan harga terjanpkau; atraksi yanp tersedia di masinp-masing destinasi wisata per tanggal kunjungan. Sistem informasi ini digunakan untuk pengelolaan pariwisata DIY yang berkelanjutan. Pembatasan kunjunpan sesuai kapasitas masinp- masing destinasi wisata secara bertahap dapat dilakukan melalui SIAAAP. Pada tahap awal akan dibuka 50 persen dari kapasitas destinasi wisata dimulai bulan Juni —Juli 2020. Ujicoba akan dievaluasi pada pada bulan Agustus 2020. Pada tahun 2021 diharapkan kunjungan dapat dibuka 100 persen sesuai kapasitas masing-masing destinasi wisata. Penentuan kapasitas masing-masing destinasi wisata memperhatikan daya dukung lingkungan, kesehatan, sosial, dan ekonomi.

Sistem informasi mencakup pula jumlah dan kualitas amenitas di masingmasing objek wisata. Kapasitas dan ketersediaan amenitas dapat dipantau dan dipesan secara online. Wisatawan melalui SIAAAP dapat memesan tiket masuk destinasi wisata secara online. Kapasitas ketersediaan kunjungan ke destinasi wisata dapat dipantau. Wisatawan tidak perlu mengantri tiket tanda masuk destinasi wisata.

Atraksi yang terdapat pada masingmasing destinasi wisata terinformasikan pada SIAAAP. Calon wisatawan dapat memilih waktu kunjungan disesuaikan denpan keberadaan atraksi dan kapasitas ruang/tempat yang disediakan saat atraksi berlangsung. Pemesanan tiket untuk menikmati atraksi juga dapat dilakukan secara online.

Rencana aksi keempat adalah membangun SMART Tourism. SMART Tourism adalah pariwisata DIY yang berbasis teknologi informasi berkelanjutan. SMART Tourism membangun kesadaran pelaku industri pariwisata di DIY untuk menerapkan teknologi informasi dalam kegiatan usaha mereka. SMART Tourism juga membentuk perilaku pelaku industri pariwisata DIY dan pengunjung destinasi wisata DIY yang cerdas (pemanfaatan teknologi informasi, kesadaran wisata berkelanjutan, menjaga kesehatan dan kesejahteraan manusia dan lingkungan).

Tahap kedua yang akan dimulai bulan Juli hingga Desember 2020 adalah pembukaan transportasi umum secara bertahap. Pembukaan transportasi umum tentunya berkoordinasi dengan pemerintah pusat dan daerah serta pelaku industri jasa angkutan. Sebelum pembukaan transportasi umum, seluruh protokol kesehatan dan keamanan angkutan umum harus dipenuhi terlebih dahulu. Pembukaan layanan transportasi umum ini akan membuka ruang mobilitas tenaga kerja dan wisatawan berkunjung ke DIY. Destinasi wisata akan dibuka secara bertahap sesuai denpan kesiapan masing-masing pengelola destinasi wisata dalam menerapkan standar K3 di tempatnya. Kegiatanbisnis perhotelan, restoran, kuliner akan berjalan secara bertahap sesuai denpan jumlah kunjungan wisatawan di DIY. Pada tahap ini uji coba SMART Tourism dijalankan untuk menjamin kesehatan dan keselamatan pelaku industri maupun wisatawan. Pemantauan dilakukan secara online karena sistem informasi yang telah terintegrasi di sektor pariwisata. Uji coba SMART Tourism ini dilakukan untuk mengevaluasi apakah seluruh protokol pariwisata berkelanjutan yang telah disusun telah dipatuhi bukan hanya pelaku industri pariwisata, namun juga pengunjung. Pengembangan SMART Tourism dapat dilakukan melalui umpan balik hasil uji coba ini. SMART Tourism akan merubah paradigma pariwisata massal menjadi pariwisata berkelas. Pariwisata berkelas adalah pariwisata yang memperhatikan kapasitas daya dukung lingkungan masing-masing destinasi wisata. Lingkungan yang dimaksud adalah lingkungan alam, sosial, budaya, dan ekonomi dimana destinasi wisata berada.

Tahap ketiga adalah proses pemulihan industri pariwisata DIY di Tahun 2021. SMART Tourism diharapkan dapat diimplementasikan sepenuhnya, tidak ada lagi pelanggaran terhadap protokol wisata berkelanjutan yang dilakukan oleh pelaku industri maupun wisatawan. Destinasi wisata di DIY terus 
dibuka secara bertahap sesuai kesiapan masing-masing pengelola memenuhi protokol wisata berkelanjutan. Kegiatan hotel, restoran dan industri pendukung pariwisata lainnya terus dipulihkan secara bertahap melalui kebijakan makro maupun mikro prudensial.

Pada akhir tahun 2022 diharapkan pariwisata DIY telah berhasil pulih denpan SMART Tourism. Pariwisata berkelanjutan berbasis teknologi informasi. Pariwisata yang memberikan kesejahteraan manusia dan lingkungannya

\section{KESIMPULAN}

Pariwisata merupakan salah satu sektor yang terkena dampak cukup parah akibat pandemi COVID-19. Pertumbuhan wisatawan dan tingkat hunian hotel di DIY nepatif selama masa pandemi COVID-19. Banyak industri pariwisata mengalami kerugian, sehingga terpaksa melakukan pemutusan hubungan dengan karyawan. Banyak karyawan di industri pariwisata dirumahkan tanpa dibayar.

Sektor pariwisata merupakan sektor andalan di DIY. Peran sektor pariwisata bapi perekonomian DIY cukup dominan. Kegiatan pariwisata melibatkan banyak pelaku industri. Krisis di sektor pariwisata akan berdampak pada krisis di sektorsektor pendukungnya. Ada empat sektor kunci di DIY, yaitu (1) Industri Kayu, Rotan dan Bambu; (2) Hotel dan Restoran; (3) Angkutan Udara; dan (4) Komunikasi. Keempat sektor tersebut memiliki keterkaitan erat ke depan dan ke belakang. Krisis yang terjadi pada keempat sektor tersebut akan menarik sektor-sektor yang terkait dengan keempatnya untuk ikut mengalami krisis.

Pemulihan sektor pariwisata di DIY tidak dapat dilakukan secara cepat. Ada beberapa tahapan yang harus dilalui. Pariwisata di DIY perlu digeser dari mengandalkan pariwisata massal menjadi pariwisata kelas. Pengunjung destinasi wisata dibatasi sesuai kapasitas optimal menuju pariwisata berkelanjutan. Pengembangan SMART Tourism memerlukan inovasi pariwisata di DIY berbasis teknologi informasi. Kolaborasi antara pelaku industri pariwisata, pemerintah, perguruan tinggi, dan masyarakat diperlukan agar SMART Tourism dapat dibangun dan dikembangkan.

Melalui pengembangan pariwisata yang inovatif dan pemenuhan protokol kesehatan serta standarisasi layanan wisata berstandart internasional, pariwisata di DIY diharapkan akan pulih di tahun 2022 Tahun 2020 merupakan tahun pengembangan SMART Tourism melalui aplikasi visiting jogja dan Jogja Pas. Tahun 2021 merupakan tahun pelaksanaan SMART Tourism secara optimal. Tahun 2022 diharapkan menjadi tahun pulihnya sektor pariwisata di DIY yang lebih berkualitas dan terpercaya.

\section{DAFTAR PUSTAKA}

Alvarez-Sousa, A., Prados, J. L. P., (2020) Visitor management in world heritage destinations before and after covid-19, Angkor.

Bakar, N. A., \&Rosbi, S. (2020). Effect of Coronavirus disease (Covid-19) to tourism industry. International JurnalOf Advanced

Bank Indonesia.(2020). Kumpulan Working Paper, Kantor perwakilan Bank Indonesia Daerah Istimewa Yogyakarta, Halaman 49-67.

Bautista, H., Valeeva, G., Danilevich, V., (2020). A Development strategy for the revival of tourist hotspots following the covid-19 pandemic.

Creswell, J. W., Reseach Design; Pendekatan

Kualitatif, Kuantitatif, dan Mixed, (Yogjakarta: Pustaka Pelajar, 2007), hlm. 167.

Chaudhary, M., Sodani, P.R., Das, S., 2020, "Effect of COVID-19 on Economy in India: Some Reflections for Policy and Programme" vol 22. No.1 page 169-180.

Collins-Kreiner, N., Ram, Y., (2020). National tourism strategies during the Covid-19 pandemic.

Dinas Pariwisata, D. I. Y. (2019). Statistik Kepariwisataan 2014. Yogyakarta, DIY. Retrieved Juli (Vol. 26).D.I. Yogyakarta Indonesia.

Dolnicar, S., \&Zare, S. (2020). COVID19 and Airbnb: Disrupting the disruptor. Annals of Tourism Research. 
Gossling, S., Scott, D., \& Hall, C. M. (2020). Pandemics, tourism, and global change: A rapid assessment of Covid-19. Journal of Sustainable Tourism.

Head, B. W. (2007). Three lenses of evidence-based policy. The Australian Journal of Public Administration, 67(1), 1-11. https://doi.org/10.1111/j.1467-8500. Osborne, S. P., \& Brown, K. (2005).Managing change and innovation in public service organizations.Routledge.

Loayza, N. V., \& Pennings, S. (2020). Macroeconomic policy in the time of COVID-19: Aprimer for developing countries.

Loi, K. L., Lei, W. S., Lourenço, F., (2020) Understanding the reactions of government and gaming concessionaires on COVID-19 through the neo-institutional theory - The case of Macao.

McGinlay, J., dkk, 2020, "The impact of COVID-19 on the management of European protected areas and policy implications", Forests vol.11 No.11 page 1-15.

Muhamad, N. A. S., Poni, S. K. (2020). Analisis Faktor Pendukung dan Penghambat Pengelolaan Atraksi Wisata Air Mancur Sri baduga.

Nur, R., Dwiyono, R.S., Amin, K. (2020). Strategi Pengelolaan Pantai Banyu tibo Berbasis Ekowisata di Kabupaten Pacitan Jawa Timur.

Ritchie, B. W., \& Jiang, Y. (2019).A review of research on tourism risk, crisis, and disaster management. Annals of Tourism Research,

Sugiyono. (2011). Metode Penelitian Kuantitatif, Kualitatif, dan R\&D. Bandung: Penerbit Alfabeta.

Wen,J., Wang,W., Kozak, M., Liu,X., \&Hou,H. (2020). Many brains are better hanone: the importance of interdisciplinary studies on COVID-19 in and beyond tourism. ToUriSm Recreation Research, 1-4. World Health Organization. (2020). Corona virus disease 2019 (COVID-19): situation report,57.
Yang, Y., Zang, H., \& Chen, X. (2020). Coronavirus pandemic and tourism: Dynamic stochastic general equilibrium modeling of infectious disease outbreak. Annals of Tourism Research 